\title{
A Historical Look at Changing Water Quality in the Delaware River Basin
}

In 2019 the U.S. Geological Survey (USGS) launched a pilot regional Integrated Water Availability Assessment (IWAA) in the Delaware River Basin (fig. 1). IWAA is intended to explore, test, and refine systems and processes for assessing water availability for human and ecological uses and understanding their underlying controls. Water quality plays an important role in supporting ecological health and determining the suitability of water for human consumption, recreation, agriculture, and industry. Understanding how water quality has changed over time in response to natural and human-induced changes in landscape and climate identifies potential challenges in safeguarding water for all uses. The USGS has evaluated water-quality trends across the Nation, and 22 of the evaluated sites are in the Delaware River Basin (Oelsner and others, 2017; Murphy and others, 2018). These 22 sites are in the Appalachian Plateau, Valley and Ridge, Piedmont, and Coastal Plain Physiographic Provinces (fig. 1). Data from these sites indicate decadal to multidecadal changes in water quality and provide an initial look at how nutrient concentrations, such as total phosphorous, total nitrogen, and nitrate, and salinity indicators, such as specific conductance, sulfate, and chloride, have varied over time in the basin. The time period of the evaluation ranged from 1972 to 2012.

\section{Changes in Water Quality Through 2012}

Across the Delaware River Basin, increases in specific conductance and chloride concentrations in rivers and streams began as early as 1972 (fig. 2) with some of the largest changes occurring at sites with the highest concentrations overall (Murphy and others, 2018). Conversely, sulfate concentrations steadily decreased during this time. For nutrient concentrations (nitrate, total nitrogen, and total phosphorous), the direction of change was less consistent among sites and the amount of change was often smaller than those seen for chloride or specific conductance. Total phosphorous and total nitrogen concentrations slightly decreased, and nitrate concentrations changed marginally (fig. 2). Spatially, some of the highest concentrations (fig. 2) occurred at sites in the Piedmont and Coastal Plain regions (fig. 1).

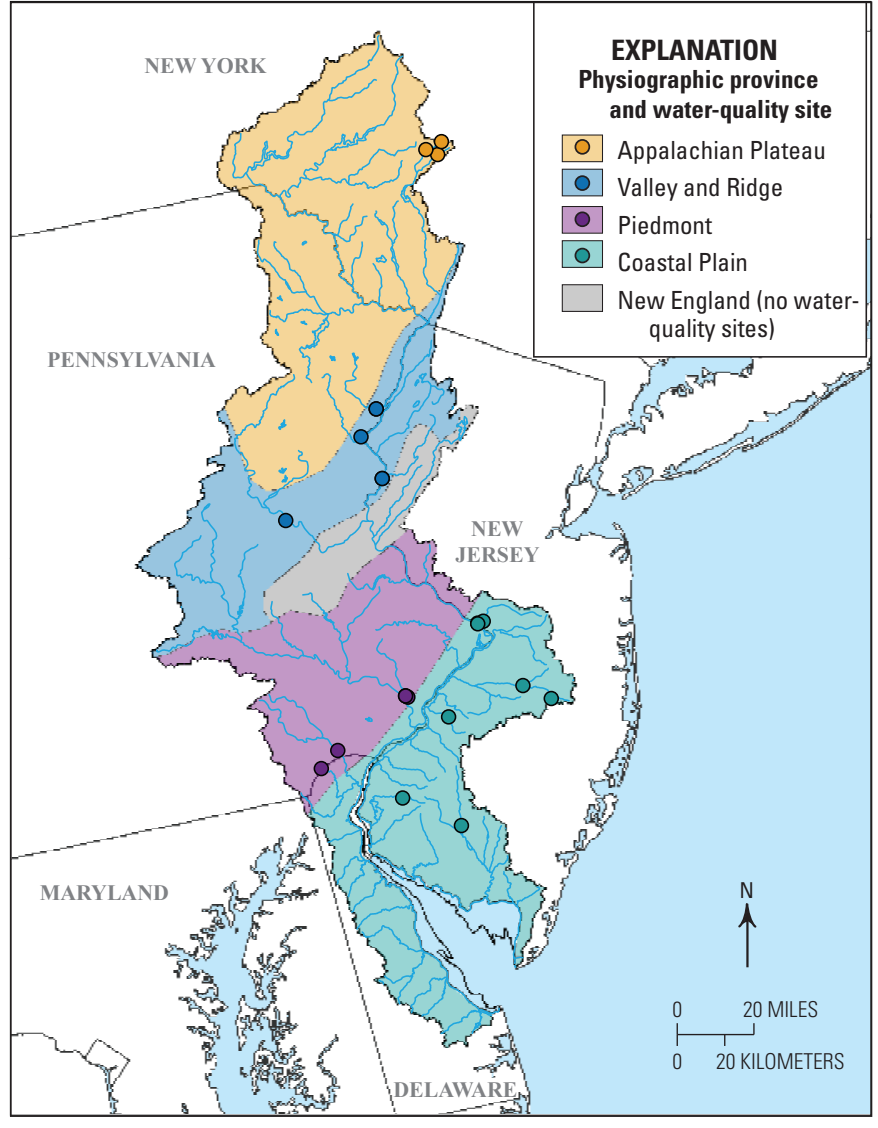

Figure 1. Sites in the National-scale trend study (Oelsner and others, 2017) located in the Delaware River Basin. No sites are located in the New England Physiographic Province.
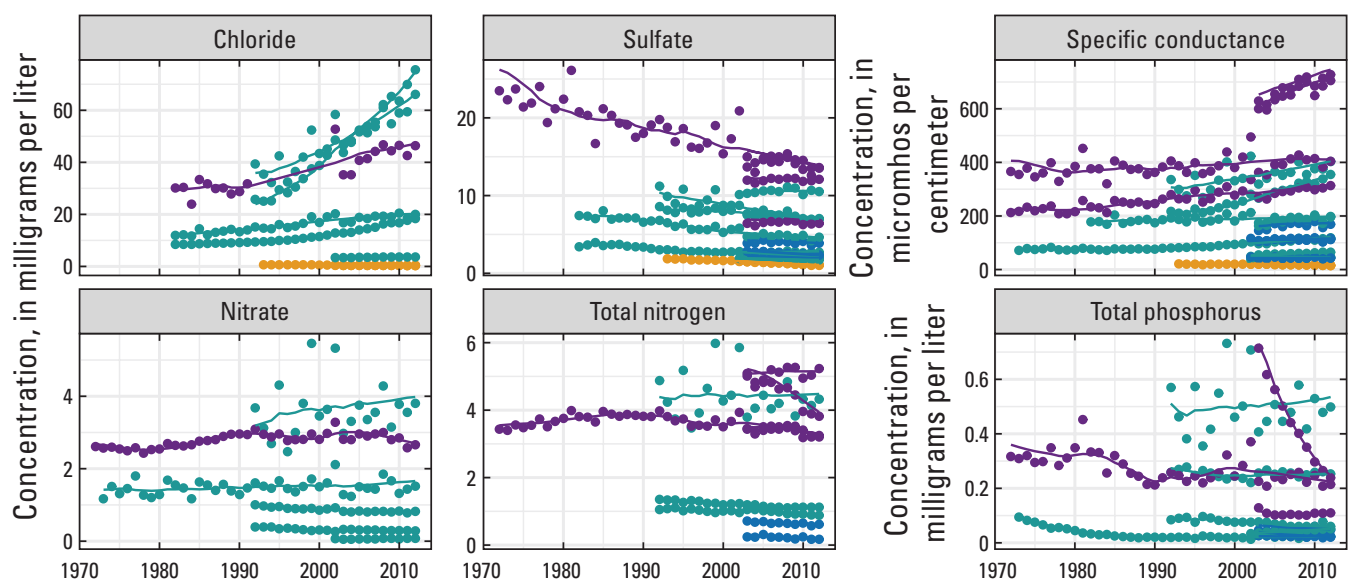

\section{EXPLANATION}

Physiographic province

$\rightarrow \quad$ Appalachian Plateau

$\rightarrow$ Coastal Plain

$\rightarrow$ Piedmont

$\rightarrow \quad$ Valley and Ridge

Figure 2. Time-series plots of annual mean concentrations of selected water-quality parameters for 22 sites in the Delaware River Basin that were a part of the National-scale trend study (Oelsner and others, 2017). The number of sites varies depending on the water-quality parameter. 


\section{Nutrient Runoff}

Over the past decade or more, small decreases or little change in nutrient concentrations and loads (total phosphorous, total nitrogen, and nitrate) at sites in the basin are an encouraging sign for the maintenance of healthy waters, especially given that many estuaries in the mid- and North Atlantic States are highly susceptible to eutrophication, and population continues to increase in many areas (Oelsner and Stets, 2019). The small decreases in nitrogen and phosphorus observed in the basin (fig. 2) also occur elsewhere in the mid- and North Atlantic States and bode well for minimizing the potential for harmful algal blooms which are becoming prevalent in large rivers and estuaries (Oelsner and Stets, 2019).

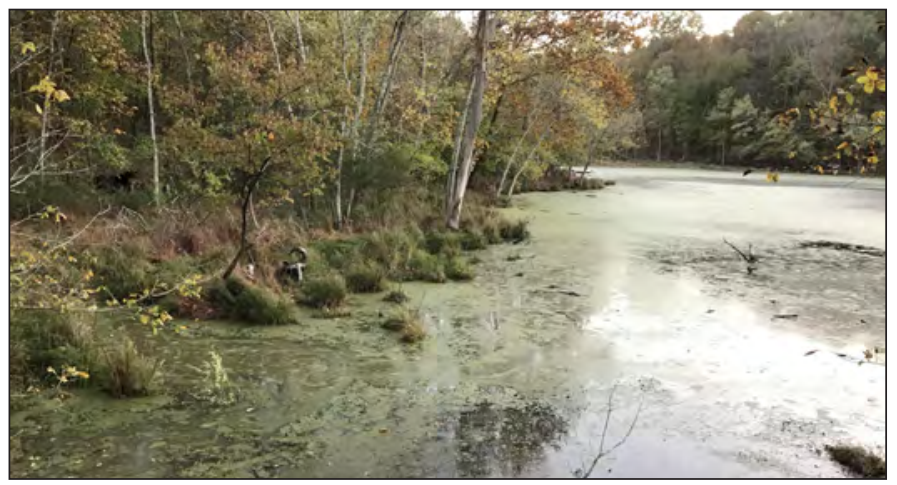

Photograph of algae. Photograph by Jennifer Murphy, U.S. Geoological Survey.

\section{Potential Corrosivity}

Increases in specific conductance and chloride coupled with decreases in sulfate indicate that rivers and streams may be becoming increasingly corrosive across the Delaware River Basin (fig. 1). Urban, snow-affected areas like the Delaware River Basin had larger increases in chloride levels since the early 1980s and 1990s compared to other areas of the Nation and other basins with less urban land uses (Stets and others, 2018). The effect of increasing stream-water corrosivity on drinking water systems is unclear. However, lead action-level exceedances in drinking water tend to be higher where the water being treated has higher amounts of chloride compared to sulfate (Stets and others, 2018). The likely source of elevated chloride concentrations in areas like the Delaware River Basin is the use of road salt during the winter and balancing this need with the quality of water used as a drinking source is a challenge with no clear solution (Stets and others, 2018).

\section{Effects of Water Quality on Water Availability}

Chloride, sulfate, and nitrate concentrations in 2012 were far below drinking water standards (fig. 2). Even though chloride has been increasing in many streams in the Delaware River Basin, all concentrations are far less than the National Secondary Drinking Water Standard of 250 milligrams per liter (mg/L) (fig. 2; U.S. Environmental Protection Agency, 2018a). Total nitrogen and total phosphorous concentrations, however, were near or above the ecoregional nutrient criteria $(0.12-0.18 \mathrm{mg} / \mathrm{L}$ for total nitrogen and $0.01-0.7625 \mathrm{mg} / \mathrm{L}$ for total phosphorous, depending on the ecoregion), which represent levels where streams might be threatened by eutrophication (U.S. Environmental Protection Agency, 2018b). The trajectory of some concentration changes in time, or a lack of change, could be problematic considering potential or anticipated changes in the landscape (for example, continued urbanization) and climate (for example, warmer temperatures and more intense precipitation) (Shoda and others, 2019).

Over the past several decades, changes in the timing, magnitude, and variability of streamflow have influenced chemical and sediment concentrations and loads in many streams across the Nation (Murphy and Sprague, 2019). Particularly, the frequency of high streamflows has increased across the northeastern United States resulting in changes to stream chemistry, especially chloride and other major ions (Murphy and Sprague, 2019). In urban basins with moderate to severe winters, such

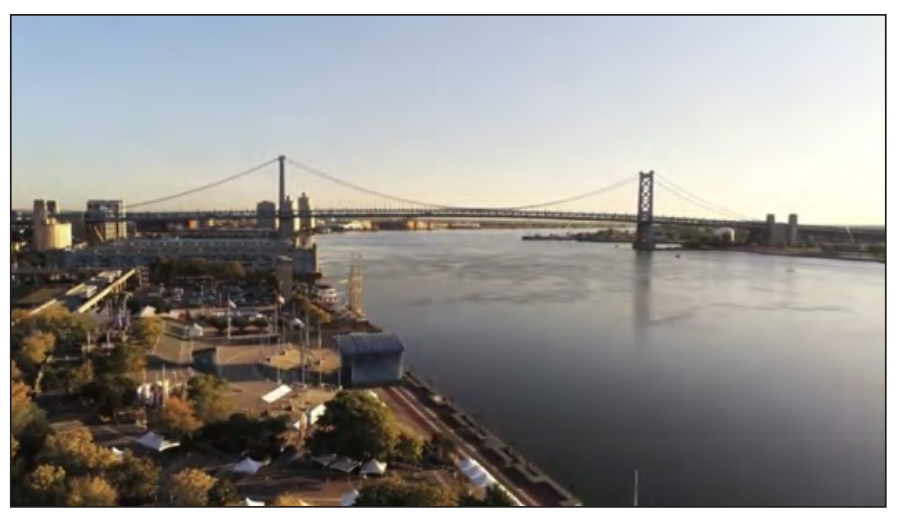

Parrot ANFI drone flown by Joe Adams, U.S. Geological Survey. Frame captured by Joseph Duris, U.S. Geological Survey.

as the Delaware River Basin, increases in chloride concentrations (fig. 2) from road salt applications and similar activities may be further exacerbated by hydrologic changes caused by global changes in climate.

\section{References Cited}

Murphy, J., and Sprague, L., 2019, Water-quality trends in US rivers-Exploring effects from streamflow trends and changes in watershed management: Science of the Total Environment, v. 656, p. 645-658, accessed December 2019 at https://doi.org/10.1016/j. scitotenv.2018.11.255.

Murphy, J.C., Farmer, W.H., Sprague, L.A., De Cicco, L.A., and Hirsch, R.M., 2018, Water-quality trends and trend component estimates for the Nation's rivers and streams using Weighted Regressions on Time, Discharge, and Season (WRTDS) models and generalized flow normalization, 1972-2012: U.S. Geological Survey data release, accessed December 2019 at https://doi.org/10.5066/F7TQ5ZS3.

Oelsner, G.P., Sprague, L.A., Murphy, J.C., Zuellig, R.E., Johnson, H.M., Ryberg, K.R., Falcone, J.A., Stets, E.G., Vecchia, A.V., Riskin, M.L., De Cicco, L.A., Mills, T.J., and Farmer, W.H., 2017, Water-quality trends in the Nation's rivers and streams, 1972-2012 - Data preparation, statistical methods, and trend results: U.S. Geological Survey Scientific Investigations Report 2017-5006, 136 p., accessed December 2019 at https://doi.org/10.3133/sir20175006.

Oelsner, G.P., and Stets, E.G., 2019, Recent trends in nutrient and sediment loading to coastal areas of the conterminous U.S.--Insights and global context: Science of the Total Environment, v. 654, p. 1225-1240, accessed December 2019 at https://doi.org/10.1016/j. scitotenv.2018.10.437.

Shoda, M.E., Sprague, L.A., Murphy, J.C., and Riskin, M.L., 2019, Waterquality trends in U.S. rivers, 2002 to 2012 - Relations to levels of concern: Science of the Total Environment, v. 650, p. 2314-2324, accessed December 2019 at https://doi.org/10.1016/j.scitotenv.2018.09.377.

Stets, E.G., Lee, C.J., Lytle, D.A., and Schock, M.R., 2018, Increasing chloride in rivers of the conterminous U.S. and linkages to potential corrosivity and lead action level exceedances in drinking water: Science of the Total Environment, v. 613-614, p. 1498-1509, accessed December 2019 at https://doi.org/10.1016/j.scitotenv.2017.07.119.

U.S. Environmental Protection Agency, 2018a, Secondary Drinking Water Standards - Guidance for nuisance chemicals, accessed May 2018 at https://www.epa.gov/dwstandardsregulations/secondary-drinkingwater-standards-guidance-nuisance-chemicals.

U.S. Environmental Protection Agency, 2018b, Ecoregional nutrient criteria for rivers and streams documents, accessed May 2018 at https:// www.epa.gov/nutrient-policy-data/ecoregional-nutrient-criteria-riversstreams-documents.

By Jennifer C. Murphy and Megan E. Shoda 